\title{
O Desafio do Idoso no Contexto Familiar na Contemporaneidade
}

\author{
Conceição, Sandra Maria da Penha; Souza, Rosana; Freitas, Marlene Gomes; Silva, \\ Suely Aquino Rodrigues \\ Uniban-Anhanguera — sandramariaenf@ig.com.br
}

Introdução: o acelerado ritmo de envelhecimento no Brasil cria novos desafios para a sociedade brasileira contemporânea. o envelhecimento ocorre num cenário de profundas transformações sociais, urbanas, industriais e familiares. a família encontra grandes dificuldades para o desempenho das funções tradicionais a ela atribuídas cuidar dos mais velhos. a família é uma importante instituição na construção de valores morais, éticos e espirituais, sendo responsável pela formação de padrões de comportamento. o núcleo familiar por si só não dispõe do básico para promover a integração social e o desenvolvimento de seus membros.Objetivo: Averiguar, através de resgate bibliográfico, itens contemporâneo referente ao desafio do idoso no convívio de idosos familiar, bem como, a partir dos dados obtidos, sugerir cuidados e atividades que possam auxiliar no cuidado e manutenção da integração do idoso ao meio familiar, social e cultural. Metodologia: Este estudo consiste em uma pesquisa de revisão literária, do tipo levantamento bibliográfico, com abordagem qualitativa. Considerações finais: É necessária a sua inclusão em programas que permitam ao idoso condições básicas de inserção social e cidadania para que ela possa cumprir o papel que the é social e legalmente atribuído incluindo o desafio do convívio na família.

Conceição, Sandra Maria da Penha; Souza, Rosana; Freitas, Marlene Gomes; Silva, Suely Aquino Rodrigues. O Desafio do Idoso no Contexto Familiar na Contemporaneidade. In: Anais do Congresso Internacional de Humanidades \& Humanização em Saúde [= Blucher Medical Proceedings, num.2, vol.1]. São Paulo: Editora Blucher, 2014. ISSN 2357-7282

DOI 10.5151/medpro-cihhs-10834 